\title{
Wpływ parlamentów narodowych na Komisję Europejską podczas procedury żółtej kartki w sprawie zmiany dyrektywy dotyczącej delegowania pracowników ${ }^{2}$
}

\section{Streszczenie}

Niniejszy artykuł ma na celu analizę możliwości oddziaływania parlamentów narodowych na Komisję Europejską w ramach procedury żółtej kartki. Badania opierają się na aktywności parlamentów narodowych wybranych państw Europy Zachodniej oraz Europy Środkowo-Wschodniej w okresie między ogłoszeniem wniosku Komisji Europejskiej dotyczącego rewizji dyrektywy 96/71/WE dotyczącej delegowania pracowników w ramach świadczenia usług a decyzją Komisji dotyczącą podtrzymania tegoż wniosku. Analizie poddane zostały trzy zmienne dotyczące państw wybranych do analizy, tj. interes gospodarczy, spójność przedstawianych przez parlamenty stanowisk oraz aktywność parlamentów, w tym ich członków, na arenie międzynarodowej.

Słowa kluczowe: Komisja Europejska, wpływ, parlament narodowy, delegowanie pracowników, zasada pomocniczości, żółta kartka, uzasadniona opinia

Małgorzata Wysocka - doktorantka w Katedrze Prawa Europejskiego Wydziału Prawa i Administracji Uniwersytetu Warszawskiego; e-mail: malgorzata.wysocka@coleurope.eu; ORCID: 0000-0002-5815-7735.

2 Artykuł przygotowany na podstawie pracy magisterskiej sporządzonej w ramach studiów na kierunku European Political and Administrative Studies na College of Europe w Brugii w 2017 roku. 


\title{
The influence of national parliaments on the European Commission within the framework of the yellow card procedure in the context of the revision of the Posting of Workers Directive
}

\begin{abstract}
The article aims to analyse the national parliaments' capability of exerting influence on the European Commission in the framework of the yellow card procedure. The analysis is based on the actions undertaken by national parliaments of selected Member States from Western as well as Central and Eastern Europe within the period between the announcement of the European Commission proposal for a targeted revision of Directive 96/71/EC on the posting of workers and its decision to maintain the proposal. The analysis covers three variables concerning the states selected for analysis, namely the economic interest of those states, the coherence of their parliaments' respective positions and the actions undertaken by the national parliaments, including those of their members, on the international level.
\end{abstract}

Keywords: European Commission, influence, national parliaments, posting of workers, subsidiarity, yellow card, reasoned opinion 


\section{Wstęp}

Traktat z Lizbony, nazywany „Traktatem parlamentów”, wzmocnił rolę nie tylko Parlamentu Europejskiego, lecz również parlamentów narodowych, przyznając im prawo do uczestnictwa w procesie tworzenia prawa na poziomie unijnym poprzez zgłaszanie zastrzeżeń $\mathrm{w}$ stosunku do propozycji ustawodawczych w obszarach, w których Unia nie ma kompetencji wyłącznych ${ }^{3}$.

28 czerwca 2018 r. doszło do przełomowego wydarzenia, które będzie miało wpływ na ogromną liczbę europejskich przedsiębiorstw, a w konsekwencji, na gospodarkę państw europejskich. Wydarzeniem tym było podpisanie przez przewodniczącego Parlamentu Europejskiego i przewodniczącego Rady UE dyrektywy Parlamentu Europejskiego i Rady (UE) 2018/957 z dnia 28 czerwca 2018 r. zmieniającej dyrektywę 96/71/WE dotyczącą delegowania pracowników w ramach świadczenia usług. Oficjalne rozmowy dotyczące zmiany dyrektywy 96/71/WE Parlamentu Europejskiego i Rady z dnia 16 grudnia 1996 r. dotyczącej delegowania pracowników w ramach świadczenia usług („Dyrektywa”), rozpoczęły się od zaprezentowania przez Komisję Europejską („Komisja”) 8 marca 2016 roku wniosku ustawodawczego („Wniosek”) ${ }^{4}$. Zarówno sam pomysł zmiany zasad delegowania pracowników, jak i przepisy zawarte w projekcie rozpoczęły gorącą debatę między zwolennikami i przeciwnikami zaostrzenia przepisów. Państwa członkowskie Unii Europejskiej podzieliły się na dwa obozy w większości według linii Wschód-Zachód. Jednym z najciekawszych z perspektywy prawa unijnego wydarzeń związanych z proponowanymi zmianami była uruchomiona przez 14 izb parlamentarnych z 11 państw członkowskich procedura żółtej kartki, tj. uzasadnionej opinii o niezgodności projektu aktu ustawodawczego z zasadą pomocniczości opartej na art. 5 ust. 3 Traktatu o Unii Europejskiej ${ }^{5}$, po której Komisja miała obowiązek poddać projekt ponownej analizie, dokonać ewentualnych zmian, wycofać

3 D. Jancic, The game of cards: National Parliaments in the EU and the future of the Early Warning Mechanism and the political dialogue, "Common Market Law Review" 2015, Vol. 52, 2015, s. 939.

4 Wniosek Komisji Europejskiej z dnia 8 marca 2016 r. w sprawie Dyrektywy Parlamentu Europejskiego i Rady zmieniającej dyrektywę 96/71/WE Parlamentu Europejskiego i Rady z dnia 16 grudnia 1996 r. dotyczącą delegowania pracowników w ramach świadczenia usług, 2016/070 (COD), Strasburg, 8 marca 2016.

5 Traktat o Unii Europejskiej, Dziennik Urzędowy Unii Europejskiej C 202 z 7 czerwca 2016, s. 13-45. 
go lub podtrzymać w wersji niezmienionej, a następnie wydać oficjalny dokument uzasadniający decyzję.

Niniejszy artykuł przedstawia analizę mającą na celu wyjaśnienie, dlaczego parlamenty państw Europy Zachodniej zdołały wywrzeć większy wpływ na decyzję Komisji dotyczącą kontynuacji prac nad zmianą Dyrektywy niż parlamenty Europy Środkowo-Wschodniej.

Analiza skupia się na okresie między ogłoszeniem Wniosku a decyzją Komisji dotyczącą podtrzymania Wniosku ${ }^{6}$, tj. między 8 marca a 20 lipca 2016 r. i oparta jest na badaniu oficjalnych dokumentów przyjętych przez omawiane izby w ramach kontroli zasady pomocniczości, dialogu politycznego, a także stenogramów spotkań międzyparlamentarnych oraz posiedzeń parlamentów narodowych i odpowiednich ich komisji, jak również przeprowadzonych wywiadów i danych statystycznych z 2015 roku.

Do badania wybrane zostały izby parlamentarne Francji (Zgromadzenie Narodowe i Senat) i Niemiec (Bundestag i Bundesrat) jako najważniejszych przedstawicieli państw przyjmujących pracowników delegowanych oraz izby parlamentów Polski (Sejm i Senat) oraz Czech (Izba Poselska i Senat) jako przedstawicieli państw członkowskich, które próbowały powstrzymać zaostrzenie przepisów Dyrektywy. Analizie poddane zostały trzy zmienne dotyczące państw wybranych do analizy, tj. interes gospodarczy, spójność przedstawianych przez parlamenty stanowisk oraz aktywność parlamentów (w tym ich członków) na arenie międzynarodowej.

\section{Nakreślenie kontekstu}

\section{Delegowanie pracowników w ramach świadczenia usług}

Delegowanie pracowników uregulowane jest przez Dyrektywę, która znajduje zastosowanie do przedsiębiorstw prowadzących działalność w państwie członkowskim, które w ramach świadczenia usług poza jego granicami tymczasowo:

$\square$ delegują pracowników na własny rachunek i pod swoim kierownictwem $\mathrm{w}$ ramach umowy zawartej między przedsiębiorstwem delegującym a odbiorcą usług,

6 Komisja Europejska, Komunikat Komisji, Parlamentu Europejskiego, Rady i Parlamentów Narodowych w sprawie wniosku dotyczącego dyrektywy zmieniającej dyrektywę o delegowaniu pracowników, w odniesieniu do zasady pomocniczości, zgodnie z protokołem nr 2, COM(2016) 505 final, Bruksela, 20 lipca 2016. 
$\square$ delegują pracowników do zakładu albo przedsiębiorstwa należącego do grupy przedsiębiorców,

$\square$ jako przedsiębiorstwo pracy tymczasowej lub agencja wynajmująca personel wynajmuje pracownika przedsiębiorstwu, prowadzącemu działalność gospodarczą lub działającemu na terytorium państwa członkowskiego. ${ }^{7}$

Głównymi zmianami zaproponowanymi przez Komisję 8 marca 2016 były: tożsamość zasad stosowanych do transgranicznych i lokalnych agencji wynajmujących pracowników,

$\square$ stosowanie do umowy o pracę pracowników delegowanych prawa pracy państwa przyjmującego, jeśli przewidywany lub faktyczny okres delegowania jest dłuższy niż 24 miesiące, o ile strony nie umówiły się co do wyboru prawa właściwego,

$\square$ podleganie przez pracowników delegowanych takim samym przepisom płacowym jak pracownicy lokalni ${ }^{8}$.

\section{Spotkania dotyczące delegowania pracowników}

W ramach czasowych opisywanego badania członkowie zainteresowanych izb uczestniczyli w spotkaniu zorganizowanym przez francuskie Zgromadzenie Narodowe 18 maja 2016 („Spotkanie międzyparlamentarne”) w celu wymiany poglądów na temat delegowania pracowników, a także w dwóch spotkaniach Konferencji Komisji Parlamentarnych ds. Unii Europejskiej („,konferencja COSAC”). Konferencja COSAC odbywa się dwa razy do roku, a w badanym okresie miały miejsce dwa spotkania - 13 czerwca 2016 w Hadze oraz 11 lipca 2016 w Bratysławie, przy czym tylko podczas drugiego parlamentarzyści mieli okazję wymienić poglądy z komisarz M. Thyssen na temat zmiany Dyrektywy.

Nakreślając kontekst spotkań, warto dodać, że każda izba parlamentu państwa członkowskiego Unii ma swojego przedstawiciela w Brukseli, którego rolą jest przede wszystkim pośrednictwo między daną izbą a innymi parlamentami. Większość z nich nie pełni żadnej politycznej funkcji. Wszyscy przedstawiciele pracują w tym samym budynku Parlamentu Europejskiego, z wyjątkiem niemieckich przedstawicieli, którzy zajmują oddzielne biuro mieszczące się poza Parlamentem.

7 Art. 1, Dyrektywa 96/71/WE Parlamentu Europejskiego i Rady z dnia 16 grudnia 1996 r. dotycząca delegowania pracowników w ramach świadczenia usług, Dziennik Urzędowy Wspólnot Europejskich L 18 z 21 stycznia 1997, s. 1-6.

8 Komisja Europejska, Komunikat..., s. 4-5. 
Chociaż artykuł przedstawia analizę działalności parlamentów narodowych w wybranym okresie, nie można pominąć faktu, że rządy i izby parlamentarne próbowały już wcześniej wywrzeć wpływ na Komisję w celu rozpoczęcia reformy dotyczącej zasad delegowania pracowników. Najbardziej aktywna w tym zakresie była Francja. 28 maja 2013 G. Savary ${ }^{9}$ z Ch. Guittet, członkowie francuskiego Zgromadzenia Narodowego, wydali Raport informacyjny ${ }^{10}$, by przekonać Komisję do rozpoczęcia przeglądu Dyrektywy. Zgodnie z tezą D. Bokhorst "parlamenty mogą mieć wpływ już na pisanie wniosku Komisji"11.

\section{Znaczenie gospodarcze delegowania}

Aby zbadać wpływ wywierany przez parlamenty narodowe na Komisję, niezbędne jest zrozumienie znaczenia delegowania dla poszczególnych krajów, zarówno z perspektywy państwa wysyłającego, jak i przyjmującego zagranicznych pracowników w ramach świadczenia usług. Pomimo szerokiej debaty i podkreślania przez państwa Europy Zachodniej negatywnego wpływu delegowania pracowników ze wschodu Europy na ich gospodarkę, w rzeczywistości w 2015 r. ta forma świadczenia usług nie przekraczała średnio $0,9 \%$ wszystkich unijnych pracowników. Wydano jedynie 2.05 mln zaświadczeń A1, tj. dokumentów stwierdzających właściwość ustawodawstwa w zakresie zabezpieczenia społecznego ${ }^{12}$.

Jeśli chodzi o wynagrodzenie, różnica w płacy minimalnej między Francją a Polską w styczniu 2015 wyniosła 1039,73 euro, gdy francuskie minimalne wynagrodzenie osiągnęło 1,458 euro, a polska płaca minimalna 1750 PLN, tj. 418,27 euro ${ }^{13}$. Różnice w warunkach pracy i płacy między pracownikami delegowanymi a lokalnymi nazywane "dumpingiem socjalnym”, Komisja mierzy, porównując średnie wynagrodzenie w kraju wysyłającym z ustawową płacą minimalną w kraju przyjmującym, gdyż pracownik delegowany zazwyczaj zarabia więcej niż minimalne

$9 \quad$ Gilles Savary pełnił funkcję posła Parlamentu Europejskiego w latach 1999 do 2009.

10 Zgromadzenie Narodowe, Rapport d'information de la commission des Affaires européennes déposé par la commission des affaires européennes sur le bilan d'activité de la commission des Affaires européennes (XIVè législature, 2012-2017), 4 kwietnia 2017, Nº 4605, s. 65.

11 D. Bokhorst, A. Schout, J.M. Wiersma, The Emperor's New Clothes? A Political Evaluation of the Early Warning Mechanism, "The International Spectator" 2015, Vol. 50, No. 2, s. 103.

12 J. Pacolet, F. De Wispelaere, Posting of workers Report on A1 portable documents issued in 2015, HIVA - KU Leuven, December 2016, s. 21.

13 Średnioważony roczny kurs euro w 2015 roku wyniósł 4,1839 zl, http://www.nbp.pl/home.aspx?f=/ kursy/arch_a.html; Eurofound, Statutory minimum wages in 2015: Pay-Q4 2014 (EurWORK topical update), Eurofound, 2017, s. 1-2. 
wynagrodzenie ${ }^{14}$. Między polskim średnim wynagrodzeniem wynoszącym w 2015-3899,78 PLN ${ }^{15}$, tj. 932,96 euro a francuską płacą minimalną różnica wynosi 541,37 euro.

W związku z powyższym zbadam, czy im większy interes gospodarczy państwa UE w delegowaniu pracowników, tym większe prawdopodobieństwo, że argumenty jego parlamentu zostaną wzięte pod uwagę przez Komisję. Przez interes gospodarczy rozumiem korzyści finansowe dla budżetu państwa powiązane bezpośrednio ze zmianą Dyrektywy bądź zatrzymaniem tych zmian. Może on zależeć od liczby przyjętych bądź wysłanych pracowników, co z kolei przekłada się na to, czy korzystniejsze dla krajowej gospodarki będzie zmniejszenie liczby przyjętych pracowników delegowanych poprzez podniesienie kosztów delegowania ${ }^{16}$, czy pozostawienie obecnie obowiązujących przepisów, które utrzymają konkurencyjność przedsiębiorstw z Europy Środkowo-Wschodniej. Aby udowodnić prawdziwość postawionego wyżej pytania, przedstawię dane dotyczące wydanych zaświadczeń A1, w podziale na kraje wysyłające i przyjmujące pracowników delegowanych, trendy związane z delegowaniem, a także argumenty użyte przez parlamentarzystów w ramach analizowanych narzędzi wpływu.

\section{Zarys pozycji w zakresie delegowania pracowników}

Krajem wysyłającym największą liczbę pracowników delegowanych jest Polska, która w 2015 r. wydała aż 463,174 zaświadczeń A1 ${ }^{17}$, podczas gdy Czechy były dopiero na 17. miejscu z wydanymi 37,174 zaświadczeniami A1 ${ }^{18}$. Pomimo znacznej różnicy w liczbie wysłanych pracowników, w obu krajach w latach 2010-2015 odnotowano wzrost liczby delegowań, co może stanowić przyczynę, dla której oba państwa chcą nadal wykorzystywać swoją konkurencyjność. Jeśli zaś chodzi o przyjmowanie pracowników delegowanych, pozycja obu krajów jest podobna. Do Czech w 2015 r. napłynęło 0,4\% wszystkich unijnych pracowników delegowa-

14 Wywiad \#4 z Urzędnikiem, DG Employment, Komisja Europejska, Bruksela, 24 kwietnia 2017.

15 Główny Urząd Statystyczny, Przeciętne miesięczne wynagrodzenie w gospodarce narodowej w latach 1950-2017, stan na 23 września 2018 roku, https://stat.gov.pl/obszary-tematyczne/rynek-pracy/pracujacy-zatrudnieni-wynagrodzenia-koszty-pracy/przecietne-miesiecznewynagrodzenie-w-gospodarce-narodowej-w-latach-1950-2017,2,1.html.

16 Zmiana Dyrektywy zakłada zmianę pojęcia "minimalnych stawek płacy" na „wynagrodzenie” oraz kraju, w którym płacone będą składki na zabezpieczenie społeczne od delegowania dłuższego niż 24 miesiące.

17 Komisja Europejska, Country factsheet - posted workers in Poland (2015), s. 1, stan na 26 kwietnia 2017, ec.europa.eu/social/BlobServlet?docId=15203\&langId=en.

18 Komisja Europejska, Country factsheet - posted workers in the Czech Republic (2015), s.1, stan na 26 kwietnia 2017, ec.europa.eu/social/BlobServlet?docId=15187\&langId=en. 
nych, podczas gdy w przypadku Polski wskaźnik ten wyniósł 1,2\%, co znacznie różni się od pozycji Francji i Niemiec w tym zakresie.

Francja i Niemcy, jako najważniejsze kraje przyjmujące pracowników delegowanych, odpowiednio z 11,9\% i 28\% wszystkich unijnych delegowań, są zainteresowane ograniczeniem napływu zagranicznych pracowników. Spośród krajów, które wysyłają największą liczbę pracowników delegowanych do omawianych państw na pierwszej pozycji jest Polska, wysyłając do Francji 16,9\%, a do Niemiec $31,7 \%{ }^{19}$. Co istotne, a zostało niejako pominięte podczas debaty, oba te kraje wysyłają wielu pracowników delegowanych. W 2015 r. Francja wydała 139,040 zaświadczeń A1, podczas gdy Niemcy 240,862, co uplasowało ten kraj na drugim miejscu, tuż za Polską ${ }^{20}$. Biorąc pod uwagę trendy w zakresie delegowania, oba kraje odnotowały wzrost liczby przyjmowanych pracowników, jednak w latach 2010-2015 to Niemcy przyjęły o 67,5\% więcej pracowników niż w 2010, podczas gdy Francja jedynie o $10,7 \%{ }^{21}$.

\section{Znaczenie argumentów gospodarczych $\mathrm{w}$ debacie}

Aby wpłynąć na decyzję Komisji, parlamenty narodowe mogły skorzystać z argumentu dotyczącego znaczenia zmiany Dyrektywy dla sytuacji gospodarczej ich państw.

Pierwszym z argumentów często podnoszonym przez kraje przeciwne zmianie Dyrektywy był brak dokładnego uzasadnienia proponowanych zmian. W ramach dialogu politycznego polski Senat zarzucił projektowi brak przedstawienia wpływu proponowanej zmiany na małe i średnie przedsiębiorstwa. Ponadto, zdaniem Senatu, Komisja nie dostarczyła szczegółowych danych na temat kosztów, jakie poniosą przedsiębiorstwa w związku z nowymi zasadami wynagradzania pracowników delegowanych ${ }^{22}$. Analogiczna wątpliwość została podniesiona przez

19 Komisja Europejska, Country factsheet - posted workers in Germany (2015), s.2, stan na 26 kwietnia 2017, http://ec.europa.eu/social/BlobServlet?docId=15188\&langId=en.

20 Komisja Europejska, Country factsheet - posted workers in France (2015), s.1, stan na 26 kwietnia 2017, http://ec.europa.eu/social/BlobServlet?docId=15194\&langId=en; Komisja Europejska, Country factsheet - posted workers in Germany..., s. 1.

21 Komisja Europejska, Country factsheet - posted workers in Germany..., s. 1; Komisja Europejska, Country factsheet - posted workers in France..., loc. cit.

22 Senat Rzeczypospolitej Polskiej, Opinia Komisji Spraw Zagranicznych i Unii Europejskiej Senatu Rzeczypospolitej dotycząca projektu Dyrektywy Parlamentu Europejskiego i Rady zmieniająca dyrektywę 96/71/WE Parlamentu Europejskiego i Rady z dnia 16 grudnia 1996 r. dotyczącą delegowania pracowników w ramach świadczenia usług COM (2016) 128 przyjęta na posiedzeniu w dniu 12 kwietnia 2016, s. 1. 
czeski Senat ${ }^{23}$.Zagadnienie dotyczące zmiany zasad wynagrodzenia z minimalnych stawek na obowiązujące w państwie przyjmującym podniesione zostało zarówno przez czeski Senat, jak i przez Sejm ${ }^{24}$. Czeska Izba Poselska w swej uzasadnionej opinii przedstawiła wpływ zmiany Dyrektywy na budżet państwa, co wydaje się ciekawym narzędziem, by pokazać Komisji, że zmiana przepisów ma duży wpływ na państwo, a nawet oferowanie minimalnego wynagrodzenia w państwie przyjmującym może podwyższać pozycję społeczną pracownika delegowanego choćby do Niemiec ${ }^{25}$.

Odpowiedzi Komisji na opinie wydane przez cztery omówione powyżej izby są w dużym stopniu tożsame, co zostało odebrane jako osłabienie roli parlamentów narodowych w procedurze ${ }^{26}$. Komisja twierdziła, iż nie miała na celu wyrównania poziomu wynagrodzeń w Unii, a jedynie ujednolicenie norm dotyczących wynagrodzenia, które obowiązują pracowników lokalnych i delegowanych w przyjmującym państwie członkowskim ${ }^{27}$. W kwestii wpływu zmiany Dyrektywy na małe i średnie przedsiębiorstwa Komisja podkreśliła, iż propozycje zawarte we Wniosku mogą zmniejszyć, choć nie całkowicie usunąć, konkurencyjność związaną z kosztami pracy małych i średnich przedsiębiorstw z krajów o niskich płacach, z uwagi na różnice, które nadal będą występować w składkach na ubezpieczenie społeczne i w podatkach ${ }^{28}$.

Chociaż postulaty Francji i Niemiec zostały w dużej mierze uwzględnione we Wniosku, przedstawiciele tych krajów uczestniczyli w debacie, choć w ograniczonym zakresie. Działanie to znajduje uzasadnienie w literaturze dotyczącej wywierania

23 Senat Republiki Czeskiej, $416^{\text {th }}$ Resolution of the Senate on the Proposal for a Directive of the European Parliament and of the Council amending Directive 96/71/EC of the European Parliament and of the Council of 16 December 1996 concerning the posting of workers in the framework of the provision of services, COM (2016) 128, 27 kwietnia 2016, s. 2.

24 Sejm Rzeczypospolitej Polskiej, Uzasadniona opinia Sejmu Rzeczypospolitej Polskiej z dnia 13 kwietnia 2016 r. zawierająca powody, dla których Sejm uznaje, że projekt dyrektywy Parlamentu Europejskiego i Rady zmieniającej dyrektywę 96/71/WE Parlamentu Europejskiego i Rady z dnia 16 grudnia 1996 r. dotyczącą delegowania pracowników w ramach świadczeniu usług nie jest zgodny z zasadą pomocniczości, s. 2.

25 Parlament Republiki Czeskiej, Izba Poselska, 263rd Resolution of the Committee on European Affairs at its 49th meeting on 31 March 2016 on the Proposal for a Directive of the European Parliament and of the Council amending Directive 96/71/EC of the European Parliament and of the Council of 16 December 1996 concerning the posting of workers in the framework of the provision of services (COM (2016) 128 final), s. 5.

26 Wniosek oparty na wywiadach przeprowadzonych w Brukseli w 2017 roku.

27 Komisja Europejska, Odpowiedź na Uzasadnioną opinię przyjętą przez Polski Sejm, C (2016) 4827 final, Bruksela, 20 lipca 2016, s. 2.

28 Komisja Europejska, Reply to the Reasoned Opinion issued by Polish Senate, C (2016) 4831 final, Bruksela, 20 lipca 2016, s. 3. 
wpływu, która stwierdza, że aktorzy mogą być mniej aktywni, gdy decyzja jest zgodna $\mathrm{z}$ ich oczekiwaniami ${ }^{29}$.

Komisje ds. Europejskich i ds. Socjalnych francuskiego Zgromadzenia we wspólnym projekcie Rezolucji Europejskiej (który stanowił część Raportu Informacyjnego $\left.0^{30}\right)^{31}$ dotyczącej Wniosku, nie wypowiadają się na temat wpływu zmiany Dyrektywy na gospodarkę Francji. Rezolucja odnosi się jednak do potrzeby zmiany Dyrektywy, która ich zdaniem umożliwia tworzenie rynku taniej siły roboczej. Ponadto Zgromadzenie wyraziło zadowolenie z faktu, iż Komisja dokonuje zmiany Dyrektywy zgodnie z zasadą równości wynagrodzeń za taką samą pracę. Izba uważa, że delegowanie nie może stanowić równoległego rynku pracy, ale musi pozostać mechanizmem wsparcia dla rzeczywistej wymiany towarów i usług na rynkach międzynarodowych ${ }^{32}$. Zgromadzenie podnosi również, jakoby delegowanie pracowników było sprzeczne z zasadą wolnej i uczciwej konkurencji na wewnętrznym rynku europejskim, a delegowanie pracownika, który nie korzysta z tych samych warunków pracy i wynagrodzenia ani z takiej samej ochrony socjalnej jak pracownik lokalny, stanowiło obejście zasady pomocniczości polityki wynagrodzeń i polityki społecznej. Ponadto Zgromadzenie dowodziło, że dotychczas obowiązujące przepisy doprowadziły do destabilizacji poszczególnych sektorów, jak przemysł budowlany, na czym skorzystały przedsiębiorstwa, które wybrały międzynarodowych usługodawców wykorzystujących pracowników. ${ }^{33}$ Aby zilustrować zakres przedmiotowego zagadnienia, Komisja ds. Europejskich francuskiego Zgromadzenia przytoczyła w Raporcie Informacyjnym dane statystyczne ${ }^{34}$.

Podczas Spotkania międzyparlamentarnego G. Savary przedstawił, w obecności przedstawicieli Komisji, wpływ delegowania na krajowy system ubezpie-

29 A. Dür, Measuring Interest Group Influence in the EU. A note on Methodology, "European Union Politics" 2008, Vol. 9, s. 56.

30 Zgromadzenie Narodowe, Rapport d'Information déposé par la Commission des Affaires Européennes sur la proposition de directive du Parlement européen et du Conseil modifiant la directive 96/71/CE du Parlement européen et du Conseil du 16 décembre 1996 concernant le détachement de travailleurs (COM(2016) 128 final).

31 Ostateczna wersja dokumentu przyjęta 13 sierpnia 2016 r. nie mogła zostać poddana analizie w pracy, gdyż wydana została poza ramami czasowymi przyjętymi przy niniejszej pracy, jednak nie różni się ona znacznie od omawianej wersji.

32 Projekt Rezolucji Europejskiej, Proposition de Résolution Européenne sur la proposition de directive du Parlement européen et du Conseil modifiant la directive 96/71/CE du Parlement européen et du Conseil du 16 décembre 1996 concernant le détachement de travailleurs (COM[2016] 128 final), Assemblée Nationale, $\mathrm{N}^{\circ} 3951$, s. 32.

33 Ibidem.

34 Zgromadzenie Narodowe, Rapport d'Information déposé par la Commission des Affaires Européennes..., s. 9. 
czenia społecznego, którego fundusz zmniejsza się, gdyż coraz większa liczba pracowników nie płaci składek. Wcześniejsza, trzymiesięczna przynależność do ubezpieczenia społecznego kraju wysyłającego i praca na rzecz pracodawcy wysyłającego pracowników delegowanych została podniesiona przez francuski Senat $\mathrm{w}$ opinii politycznej przesłanej w ramach dialogu politycznego ${ }^{35}$.

Odpowiedzi Komisji Europejskiej na francuskie dokumenty były krótkie i niezbyt rozwinięte w zakresie kwestii podnoszonych przez te instytucje. Należy jednak pamiętać, iż argumenty tej strony debaty są zgodne z argumentami podnoszonymi przez Komisję Europejską.

Niemieckie izby parlamentarne nie były tak aktywne publicznie. Bundesrat wydał rezolucję dotyczącą zmiany Dyrektywy ${ }^{36}$, jednak nie przesłał jej oficjalną drogą do Komisji, gdyż była ona elementem wymiany między Izbą a rządem federalnym, który prowadzi negocjacje w imieniu Niemiec w Brukseli ${ }^{37}$. D. Kolat, członkini Bundesratu poinformowała uczestników Spotkania międzyparlamentarnego, w tym przedstawiciela Komisji, o powyższej rezolucji i podkreśliła przypadki oszustwa, obchodzenia lub naruszania przepisów przez pracodawców. Z zadowoleniem przyjęła zmiany dotyczące obowiązywania prawa pracy kraju przyjmującego, jak i zasad zabezpieczenia społecznego"38.

\section{Aktywność parlamentów narodowych i spójność ich stanowisk}

Parlamenty narodowe mogły wpływać na stanowisko Komisji dzięki spójności argumentów i swej aktywności w ramach omawianych kanałów wpływu. Zbadam, czy prawdziwe jest twierdzenie, że im spójniejsze jest stanowisko parlamentów narodowych, tym większy jest ich wpływ na decyzję Komisji. Spójność w artykule

35 Senat Republiki Francuskiej, Commission des Affaires européennes, Avis Politique sur la proposition de révision ciblée de la directive 96/71/CE relative au détachement des travailleurs (COM (2016) 128 final), Paris, 26 maja 2016, s. 2.

36 Bundesrat, Vorschlag für eine Richtlinie des Europäischen Parlaments und des Rates zur Änderung der Richtlinie 96/71/EG des Europäischen Parlaments und des Rates vom 16. Dezember 1996 über die Entsendung von Arbeitnehmern im Rahmen der Erbringung von Dienstleistungen COM(2016) 128 final, 22 kwietnia 2016.

37 Wywiad \#11 przeprowadzony poprzez e-mail z Korespondentem IPEX Bundesratu, 24 kwietnia 2017; Wywiad \#7 przeprowadzony poprzez e-mail z Korespondentem IPEX Bundestagu, 5 kwietnia 2017.

38 Stenogram ze Spotkania międzyparlamentarnego zorganizowanego przez francuskie Zgromadzenie Narodowe na temat delegowania pracowników, 18 maja 2016, s. 13-14. 
rozumiem jako podobne wykorzystanie zbliżonych argumentów, udział w spotkaniach na przedmiotowy temat oraz częstotliwość działań w stosunku do Komisji.

Analiza omawianych kanałów wpływu pomoże również ocenić, czy prawdziwa jest teza, że im bardziej aktywne są parlamenty narodowe na arenie międzynarodowej, tym bardziej wpływowe są ich stanowiska. Zbadam, czy Polska i Czechy, które wystosowały żółte kartki, by sprzeciwić się zmianie Dyrektywy, były na tyle aktywne w międzynarodowej debacie, aby wpłynąć na decyzję Komisji, a także jaka była strategia krajów, które chcą zmiany przepisów.

\section{Uzasadnione opinie i dialog polityczny}

Dokumenty przyjęte $\mathrm{w}$ analizowanym okresie różnią się w zależności od strony debaty. Parlamenty, zarzucające projektowi zmiany Dyrektywy naruszenie zasady pomocniczości, wydały uzasadnione opinie i opinię $w$ ramach dialogu politycznego, podczas gdy parlamenty popierające zmiany, uczestniczyły w dialogu politycznym, aby przekonać Komisję do przeprowadzenia reformy. Co istotne, Komisja bada uzasadnione opinie jedynie pod kątem zasady pomocniczości, nie biorąc pod uwagę argumentów merytorycznych czy politycznych ${ }^{39}$.

Za dobre narzędzie oddziaływania może być uznana rozbudowana uzasadniona opinia wydana przez Izbę Poselską, w której starała się ona przedstawić Komisji swoje poglądy oraz wpływ rewizji na budżet państwa ${ }^{40}$, poruszając między innymi problem równości wynagrodzeń za taką samą pracę, podając to samo uzasadnienie, co czeski Senat ${ }^{41}$ i polski Sejm, który pisał, iż "dostosowanie stawek płac w państwach członkowskich powinno być wynikiem stopniowego rozwoju gospodarczego" ${ }^{\prime \prime 2}$.

Wszystkie cztery izby przeciwne reformie odniosły się do zasady pomocniczości będącej istotą procedury żółtej kartki oraz argumentów gospodarczych omówionych powyżej. Trzy izby podniosły stosowanie zasad zatrudnienia określonych w układach zbiorowych do pracowników delegowanych, a jedynie czeski Senat nie rozważał tego w swej opinii. Proponowana tożsamość zasad zatrudniania stosowanych przez agencje pracy tymczasowej do pracowników lokalnych i delegowanych oraz brak odpowiedniego uzasadnienia zmiany Dyrektywy zostały podniesione przez obie polskie izby i Izbę Poselską.

\footnotetext{
39 Wywiad \#1 z Urzędnikiem, Komisja Europejska, Bruksela, 10 kwietnia 2017.

40 Parlament Republiki Czeskiej, Izba Poselska, loc. cit.

41 Senat Republiki Czeskiej, op. cit., s. 1.

42 Sejm Rzeczypospolitej Polskiej, op. cit., s. 2.
} 
Spośród francuskich i niemieckich izb w badanym okresie jedynie francuski Senat przesłał opinię w ramach dialogu politycznego. Zgromadzenie Narodowe przygotowywało w tym czasie Rezolucję europejską, o której komisarz została zapewne poinformowana. Obie francuskie izby wyraziły uznanie temu, iż Komisja podjęła inicjatywę, która ich zdaniem idzie w dobrym kierunku.

W swej opinii francuski Senat podkreślił, iż jego zdaniem Komisja powinna zaproponować dalej idące zmiany w dziedzinie wynagrodzenia, podwykonawstwa i pracy tymczasowej, a także ograniczyć czas trwania delegowania do 24 miesięcy w okresie referencyjnym 36 miesięcy. Obie francuskie izby mają podobny pogląd na reformę. Zgromadzenie Narodowe w projekcie Rezolucji europejskiej podejmuje również problem pracy tymczasowej, ograniczenia czasu trwania oraz łańcucha podwykonawstwa ${ }^{43}$.

Jeśli zaś chodzi o niemieckie izby, Bundestag nie wniósł żadnego pisemnego wkładu w debatę, natomiast Bundesrat przyjął omówioną powyżej rezolucję. Z przeprowadzonych rozmów wynika, iż przedstawiciele i członkowie niemieckich izb parlamentarnych są zazwyczaj bardzo aktywni w Brukseli, jednak nie uzyskałam dostępu do informacji, które potwierdzałyby te oświadczenia w zakresie zmiany Dyrektywy.

\section{Działania parlamentów narodowych}

Polska i Czechy, jako kraje dążące do wycofania wniosku Komisji, powinny być reprezentowane przez najbardziej aktywne parlamenty. Jedyne bezpośrednie spotkanie komisarz M. Thyssen z parlamentem przeciwnym reformie odbyło się w kwietniu 2016 r. przy okazji zaplanowanego spotkania z premierem Czech oraz Ministrem pracy i spraw społecznych, chociaż żadna z czeskich izb nie zapraszała komisarz M. Thyssen ${ }^{44}$. Podczas wspólnego posiedzenia z członkami Komisji ds. Europejskich obu izb Parlamentu jednym z omawianych tematów był przegląd Dyrektywy $^{45}$. Z badania działalności polskich izb parlamentarnych wynika, iż przewodniczący Komisji ds. Unii Europejskiej Sejmu przesłał pismo do przewodniczących innych izb europejskich parlamentów, w którym przedstawił argumenty Komisji i poprosił o dokładną analizę wniosku Komisji ${ }^{46}$.

\footnotetext{
43 Propozycja Rezolucji Europejskiej, op. cit., s. 6.

44 Wywiad \#8 przeprowadzony poprzez e-mail z Urzędnikiem, Izba Poselska Republiki Czeskiej, 5 kwietnia 2017; Komisja Europejska, Agenda, stan na 29 kwietnia 2017, https://ec.europa.eu/ commission/commissioners/2014-2019/agenda_en?field_editorial_section_multiple_tid=179.

45 Wywiad \#9 przeprowadzony poprzez e-mail z Urzędnikiem, Senat Republiki Czeskiej, 7 kwietnia 2017.

46 Wywiad \#3 z Urzędnikiem, Bruksela, 20 kwietnia 2017.
} 
Jak już wcześniej wskazałam, Francji i Niemcom udało się spełnić swoje postulaty w zakresie zmiany Dyrektywy jeszcze przed oficjalną prezentacją Wniosku, w związku z czym ich izby parlamentarne nie były zobligowane do dalszego działania i współpracy. Pomimo tego, poseł G. Savary, od lat bardzo zaangażowany w tworzenie i zmianę przepisów dotyczących delegowania pracowników, poinformował członków Komisji ds. Europejskich francuskiego Zgromadzenia Narodowego, że po jego wizycie w Niemczech zdecydowano o utworzeniu "grupy kontaktowej” w sprawie delegowania pracowników z parlamentarzystami z odpowiedniej komisji z Bundestagu ${ }^{47}$, co miało pozwolić tym izbom wypracować wspólne stanowisko i strategię dotyczącą zmiany Dyrektywy. Ponadto Zgromadzenie zorganizowało Spotkanie międzyparlamentarne, które można również postrzegać jako dobrą praktykę wpływania jednocześnie zarówno na Komisję, jak i opinię publiczną. Izba opublikowała także Raport informacyjny z załączoną propozycją Rezolucji Europejskiej. Poseł G. Savary, w ramach wymiany poglądów z podmiotami zainteresowanymi delegowaniem oraz parlamentarzystami krajów unijnych odwiedził m.in. Polskę ${ }^{48}$. Co również istotne, z racji swej aktywności i dotychczasowej działalności, poseł ten ma szerokie znajomości i doświadczenie, które niewątpliwie mogły ułatwić wpływ na Komisję w zakresie zmiany Dyrektywy. ${ }^{49}$ Jeśli zaś chodzi o francuski Senat, podczas debaty toczącej się 26 maja 2016 r. członkowie Komisji ds. Unii Europejskiej podnieśli kwestię wywierania wpływu na Komisję oraz przyjęli opinię polityczną przekazaną następnie Komisji w ramach dialogu politycznego ${ }^{50}$.

Polskie izby parlamentarne pozostały wśród najbardziej nieaktywnych w odniesieniu do prób wpływu na Komisję w analizowanym okresie, nie organizując nawet spotkania z komisarz M. Thyssen w Warszawie, by przedstawić swoje argumenty przeciwko zmianie Dyrektywy ${ }^{51}$. Jak wynika z uzyskanych informacji członek polskiego Senatu rozmawiał z komisarz M. Thyssen na temat zmiany Dyrektywy podczas jednego z oficjalnych międzynarodowych spotkań ${ }^{52}$.

47 Zgromadzenie Narodowe, Rapport d'Information déposé par la Commission des Affaires Européennes..., op. cit., s. 24.

48 Stenogram z posiedzenia Komisji ds. Socjalnych francuskiego Zgromadzenia Narodowego, Paryż, 13 lipca 2016, s.27, stan na 1 kwietnia 2017, http://www.assemblee-nationale.fr/14/cr-soc/15-16/ c1516067.asp.

49 Wywiad \#5 z Przedstawicielem parlamentu narodowego, Bruksela, 24 kwietnia 2017.

50 Stenogram z posiedzenia Komisji ds. Europejskich francuskiego Senatu, 26 maja 2016, stan na 14 kwietnia 2017, http://www.senat.fr/ue/pac/EUR000002083.html\#88-4.

51 Wywiad \#10 przeprowadzony poprzez e-mail z Urzędnikiem, Sejm Rzeczypospolitej Polskiej, 14 kwietnia 2017.

52 Wywiad \#2 z Urzędnikiem, Bruksela, 10 kwietnia 2017. 
Jeśli zaś chodzi o nieaktywne izby niemieckie, zgodnie z informacjami otrzymanymi od korespondentów Bundestagu i Bundesratu ds. platformy międzyparlamentarnej wymiany informacji w sprawach Unii Europejskiej (dalej: IPEX): „żaden członek Komisji, kolegium komisarzy ani żaden ekspert z instytucji UE nie został zaproszony do dyskusji na ten temat" ${ }^{\prime 33}$ oraz „nie wystosowano żadnego oficjalnego zaproszenia ani nie zorganizowano oficjalnego spotkania pomiędzy Komisją a członkami Bundesratu w tej sprawie - ani na szczeblu politycznym, ani na poziomie roboczym" 54 .

\section{Współpraca międzyparlamentarna}

Kolejnym badanym kanałem wpływu na Komisję było uczestnictwo w międzynarodowych spotkaniach dotyczących przeglądu Dyrektywy, na których obecni byli przedstawiciele Komisji. Podczas tych spotkań częstotliwość interwencji i spójność między przedstawicielami analizowanych państw mogły mieć wpływ na Komisję.

\section{Spotkanie międzyparlamentarne}

Chociaż Spotkanie międzyparlamentarne było dobrą okazją dla parlamentów narodowych do wyrażenia poglądów i zwiększenia znaczenia ich roli w unijnym procesie ustawodawczym, większość przemawiających pochodziła z parlamentów, które nie przesłały żółtych kartek. Polska i Czechy nie skorzystały z tej możliwości. Podczas Spotkania głos zabrali członkowie francuskiego Zgromadzenia Narodowego i Senatu oraz członek niemieckiego Bundesratu. Przemówienia francuskie były bardziej złożone i poruszały szerszy zakres argumentów. Parlamentarzyści obu francuskich izb mówili, że ochrona pracowników jest niewystarczająca. Odwołali się także do istotności problemu składek na ubezpieczenie społeczne, procedury kontroli zasady pomocniczości i łańcuchów podwykonawców, a także z zadowoleniem przyjęli wniosek w sprawie równości wynagrodzeń za taką samą pracę ${ }^{55}$. Tylko jeden francuski senator zadał pytanie, które nie wydaje się zgodne z francuską retoryką: „W jaki sposób taki poziom ochrony socjalnej, jak ten obowiązujący w naszym kraju, może zostać nałożony na kraje i przedsiębiorstwa, które nie mogą tego zapewnić?"56.

\footnotetext{
53 Wywiad \#7.

54 Wywiad \#11.

55 Stenogram ze Spotkania międzyparlamentarnego...

56 Ibidem.
} 
Jedynym członkiem niemieckiego parlamentu, który zabrał głos, była D. Kolat, która odniosła się do wyzwania, jakim dla Niemiec jest delegowanie pracowników, i z zadowoleniem przyjęła wniosek w sprawie zmiany Dyrektywy, co zostało przytoczone powyżej. Poseł dodała, iż „po upływie 24 miesięcy powinno obowiązywać prawo pracy kraju przyjmującego, podobnie jak zasady ochrony socjalnej", a także poruszyła kwestię minimalnych stawek wynagrodzenia oraz długości delegowania ${ }^{57}$.

\section{Konferencja COSAC}

Drugą okazją było posiedzenie COSAC w dniu 11 lipca 2016 r., podczas którego głównym prelegentem była komisarz $\mathrm{M}$. Thyssen, która w przemówieniu odniosła się do kontroli zasady pomocniczości, stwierdzając, że Komisja poważnie podchodzi do sygnału wysłanego przez żółte kartki, które zostały dokładnie przeanalizowane. Następnie odniosła się do „najczęstszych zastrzeżeń zgłoszonych w uzasadnionych opiniach" $^{\prime 58}$. Z treści przemówienia wynika, że decyzja w sprawie żółtych kartek została już podjęta. Podczas spotkania głos zabrali przedstawiciele polskich i czeskich parlamentów, odnosząc się do naruszenia zasady pomocniczości wyrażonej w uzasadnionych opiniach wydanych przez ich izby. Zarówno K. Głębocki, poseł polskiego Sejmu, jak i A. Maštaliř, członek czeskiego Senatu, odnieśli się do argumentów wyrażonych w uzasadnionych opiniach wydanych przez ich izby ${ }^{59}$. Jeśli chodzi o parlamentarzystów pochodzących z krajów popierających zmianę Dyrektywy, jedynym członkiem, który przemawiał był H.-J. Barchmann, członek Bundestagu, który „podkreślił, że konieczne było dojście do dobrego rozwiązania w kwestii Dyrektywy, lecz ważne jest również omówienie społecznej odpowiedzialności biznesu. Dodal, że istnieje potrzeba poprawy szkolenia pracowników"60

\section{Podsumowanie}

Na mocy Traktatu z Lizbony parlamenty narodowe zyskały możliwość zgłaszania niezgodności proponowanych aktów ustawodawczych z zasadą pomocniczości,

\footnotetext{
57 Ibidem, s. 13-14.

58 Konferencja COSAC, Minutes of the COSAC meeting, Bratislava, 11 lipca 2016, s. 7-8, stan na 12 marca 2017, http://www.cosac.eu/56-slovakia-2016/meeting-of-the-cosac-chairpersons-10-11-july2016-bratislava/.

59 Ibidem, s. 4.

60 Ibidem, s. 13-14.
} 
co daje im możliwość wpływu na politykę prowadzoną na szczeblu unijnym. Niestety, nie wszystkie izby parlamentarne krajów unijnych stworzyły mechanizmy korzystania z tej zasady. Niniejszy artykuł miał na celu przedstawić analizę działań prowadzonych przez parlamenty wybranych krajów Unii stojących po przeciwnych stronach sporu dotyczącego zmiany Dyrektywy o delegowaniu pracowników oraz sposobu, w jakich omawiane izby próbowały wpływać na Komisję Europejską w badanym okresie.

W celu odpowiedzi na pytanie, dlaczego parlamenty krajów Europy Zachodniej zdołały wywrzeć większy wpływ na decyzję Komisji Europejskiej dotyczącą kontynuacji prac nad zmianą Dyrektywy od parlamentów krajów Europy Środkowo-Wschodniej przeanalizowane zostały trzy zmienne, $\mathrm{tj}$. interes gospodarczy, spójność przedstawianych przez parlamenty stanowisk oraz aktywność parlamentów (w tym ich członków) na scenie międzynarodowej.

W zakresie pierwszej zmiennej przyjęłam, iż im większy interes gospodarczy państwa członkowskiego Unii w delegowaniu pracowników, tym większe prawdopodobieństwo, iż argumenty podnoszone przez jego parlament zostaną wzięte pod uwagę przez Komisję. Aby udowodnić wpływ znaczenia delegowania, porównałam dane dotyczące liczby pracowników wysyłanych i przyjmowanych oraz argumenty używane przez parlamentarzystów. Z analizy wynika, że francuskie i niemieckie izby rzadziej wyrażały argumenty dotyczące interesu gospodarczego. Możemy jednak założyć, że Komisja zna udział tych krajów w delegowaniu, gdyż co roku przygotowuje sprawozdania dotyczące statystyki. Co istotne, przed wydaniem Wniosku Francja (zarówno rząd, jak i parlament) próbowała przekonać Komisję do swojego stanowiska i proponowanych rozwiązań. Argumenty podnoszone przez parlamenty państw Europy Środkowo-Wschodniej dotyczące interesów gospodarczych w zakresie utrzymania obecnych ram prawnych zostały zlekceważone przez Komisję. Przedstawiona w artykule analiza pokazuje, iż parlamenty Europy Zachodniej zdołały wywrzeć większy wpływ na Komisję, ponieważ ich interes gospodarczy w zakresie zmiany zasad jest bardziej widoczny dla Komisji.

Następnie przeanalizowałam argumenty podnoszone przez parlamenty w oficjalnych dokumentach, a także podczas spotkań dotyczących delegowanie pracowników, aby zweryfikować dwie hipotezy. W zakresie twierdzenia, że im spójniejsze jest stanowisko parlamentów narodowych, tym większy jest ich wpływ na decyzję Komisji, analiza pokazała, iż spójniejsze było stanowisko przedstawiane przez parlamenty państw Europy Środkowo-Wschodniej, chociaż argumenty drugiej strony debaty były do siebie podobne. Analiza pokazuje, że francuskie izby stworzyły procedury wywierające wpływ na debaty europejskie i instytucje, $\mathrm{w}$ tym na Komisję. Niemieckie izby nie uczestniczyły w pisemnej wymianie z Komisją. W związku z powyższym druga hipoteza nie została potwierdzona, gdyż 
izby zachodnich parlamentów wprawdzie wywarły większy wpływ na decyzję Komisji, jednakże nie stało się to za sprawą spójności ich stanowisk.

Na koniec badałam zależność między aktywnością parlamentów narodowych na arenie międzynarodowej a wywieranym na Komisję wpływem. Biorąc pod uwagę pokazaną $\mathrm{w}$ artykule bierność izb niemieckich, nie można całkowicie stwierdzić, iż to aktywność tej strony debaty spowodowała pozytywną dla Francji i Niemiec decyzję Komisji. Jeśli zaś chodzi o francuskie izby parlamentarne, wykazywały one największą aktywność spośród analizowanych izb, uczestnicząc w wymianie pism z Komisją oraz organizując i aktywnie uczestnicząc w spotkaniach dotyczących delegowania pracowników. Polskie i czeskie izby uczestniczyły zarówno w procedurze żółtej kartki, jak i konferencji COSAC, jednak żaden parlamentarzysta nie wziął udziału w Spotkaniu międzyparlamentarnym.

Odnosząc się do kwestii postawionej w tytule, należy stwierdzić, iż najlepszym przykładem wywierania wpływu na Komisję są bardzo aktywne izby francuskie, zarówno przed przedstawieniem Wniosku Komisji, jak i w omawianych ramach czasowych. Wpływ na Komisję zależy od przekazywania odpowiednim osobom dokumentów merytorycznych bądź nagłaśniania spotkań i raportów przedstawiających popierane stanowiska, a także uczestnictwa w spotkaniach, podczas których można przekazywać poglądy reprezentowanej izby.

\section{Bibliografia}

\section{Akty prawne}

Dyrektywa 96/71/WE Parlamentu Europejskiego i Rady z dnia 16 grudnia 1996 r. dotycząca delegowania pracowników w ramach świadczenia usług, Dziennik Urzędowy Unii Europejskiej L 18 z 21 stycznia 1997, s. 1-6.

Traktat o Unii Europejskiej, Dziennik Urzędowy Unii Europejskiej C 202 z 7 czerwca 2016, s. 13-45.

\section{Dokumenty oficjalne}

\section{Instytucje Unii Europejskiej}

Komisja Europejska, Komunikat Komisji, Parlamentu Europejskiego, Rady i Parlamentów Narodowych w sprawie wniosku dotyczącego dyrektywy zmieniającej dyrektywę o delegowaniu pracowników, w odniesieniu do zasady pomocniczości, zgodnie z protokołem nr 2, COM(2016) 505 final, Bruksela, 20 lipca 2016.

Komisja Europejska, Wniosek Komisji Europejskiej z dnia 8 marca 2016 r. w sprawie Dyrektywy Parlamentu Europejskiego i Rady zmieniającej dyrektywę 96/71/WE Parlamentu Europejskiego i Rady z dnia 16 grudnia 1996 r. dotyczącą delegowania pracowników w ramach świadczenia usług, 2016/070 (COD), Strasburg, 8 marca 2016. 
Komisja Europejska, Agenda, stan na 29 kwietnia 2017, https://ec.europa.eu/commission/commissioners/2014-2019/agenda_en?field_editorial_section_multiple_tid $=179$. Komisja Europejska, Country factsheet - posted workers in Poland (2015), stan na 26 kwietnia 2017, ec.europa.eu/social/BlobServlet?docId=15203\&langId=en.

Komisja Europejska, Country factsheet - posted workers in the Czech Republic (2015), stan na 26 kwietnia 2017, ec.europa.eu/social/BlobServlet?docId=15187\&langId=en.

Komisja Europejska, Country factsheet - posted workers in France (2015), stan na 26 kwietnia 2017, http://ec.europa.eu/social/BlobServlet?docld=15194\&langId=en. Komisja Europejska, Country factsheet - posted workers in Germany (2015), stan na 26 kwietnia 2017, http://ec.europa.eu/social/BlobServlet?docId=15188\&langId=en. Komisja Europejska, Odpowiedź na Uzasadnioną opinię przyjętą przez Polski Sejm, C (2016) 4827 final, Bruksela, 20 lipca 2016.

Komisja Europejska, Reply to the Reasoned Opinion issued by Polish Senate, C (2016) 4831 final, Bruksela, 20 lipca 2016.

Komisja Europejska, Pacolet, Josef \& Frederic De Wispelaere, Posting of workers Report on A1 portable documents issued in 2015, HIVA - KU Leuven, December 2016.

\section{Konferencja Komisji Parlamentarnych ds. Unii Europejskiej}

Konferencja Komisji Parlamentarnych ds. Unii Europejskiej, Minutes of the COSAC meeting, Bratislava, 11 lipca 2016, stan na 12 marca 2017, http://www.cosac.eu/56-slovakia-2016/meeting-of-the-cosac-chairpersons-10-11-july-2016-bratislava/.

\section{Republika Czeska}

Parlament Republiki Czeskiej, Izba Poselska, 263rd Resolution of the Committee on European Affairs at its 49th meeting on 31 March 2016 on the Proposal for a Directive of the European Parliament and of the Council amending Directive 96/71/EC of the European Parliament and of the Council of 16 December 1996 concerning the posting of workers in the framework of the provision of services (COM (2016) 128 final).

Senat Republiki Czeskiej, $416^{\text {th }}$ Resolution of the Senate on the Proposal for a Directive of the European Parliament and of the Council amending Directive 96/71/EC of the European Parliament and of the Council of 16 December 1996 concerning the posting of workers in the framework of the provision of services, $\operatorname{COM}(2016) 128$, 27 kwietnia 2016.

\section{Francja}

Stenogram ze Spotkania międzyparlamentarnego zorganizowanego przez francuskie Zgromadzenie Narodowe na temat delegowania pracowników, 18 maja 2016.

Stenogram z posiedzenia Komisji do Spraw Socjalnych francuskiego Zgromadzenia Narodowego, Paryż, 13 lipca 2016, stan na 1 kwietnia 2017, http://www.assemblee-nationale.fr/14/cr-soc/15-16/c1516067.asp. 
Stenogram z posiedzenia Komisji do Spraw Europejskich francuskiego Senatu, 26 maja 2016, stan na 14 kwietnia 2017, http://www.senat.fr/ue/pac/EUR000002083.html\#88-4. Projekt Rezolucji Europejskiej, Proposition de Résolution Européenne sur la proposition de directive du Parlement européen et du Conseil modifiant la directive 96/71/ CE du Parlement européen et du Conseil du 16 décembre 1996 concernant le détachement de travailleurs (COM[2016] 128 final), Assemblée Nationale, $\mathrm{N}^{\circ} 3951$. Zgromadzenie Narodowe, Rapport d'Information déposé par la Commission des Affaires Européennes sur la proposition de directive du Parlement européen et du Conseil modifiant la directive 96/71/CE du Parlement européen et du Conseil du 16 décembre 1996 concernant le détachement de travailleurs (COM(2016) 128 final. Zgromadzenie Narodowe, Rapport d'information de la commission des Affaires européennes déposé par la commission des affaires européennes sur le bilan d'activité de la commission des Affaires européennes (XIVè législature, 2012-2017), 4 avril 2017, Nº 4605 .

Senat, Commission des Affaires européennes, Avis Politique sur la proposition de révision ciblée de la directive 96/71/CE relative au détachement des travailleurs (COM (2016) 128 final), Paris, 26 maja 2016.

\section{Niemcy}

Bundesrat, Vorschlag für eine Richtlinie des Europäischen Parlaments und des Rates zur Änderung der Richtlinie 96/71/EG des Europäischen Parlaments und des Rates vom 16. Dezember 1996 über die Entsendung von Arbeitnehmern im Rahmen der Er-bringung von Dienstleistungen $\operatorname{COM}(2016) 128$ final (Decision concerning the proposal for a Directive of the European Parliament an of the Council amending Directive 96/71/EC of the European Parliament and of the Council of 16 December 1996 concerning the posting of workers in the framework of the provision of services (COM(2016) 128 final), 22 kwietnia 2016.

\section{Polska}

Senat Rzeczypospolitej Polskiej, Opinia Komisji Spraw Zagranicznych i Unii Europejskiej Senatu Rzeczypospolitej dotycząca projektu Dyrektywy Parlamentu Europejskiego i Rady zmieniająca dyrektywę 96/71/WE Parlamentu Europejskiego i Rady z dnia 16 grudnia $1996 \mathrm{r}$. dotyczącą delegowania pracowników w ramach świadczenia usług COM (2016) 128 przyjęta na posiedzeniu w dniu 12 kwietnia 2016.

Sejm Rzeczypospolitej Polskiej, Uzasadniona opinia Sejmu Rzeczypospolitej Polskiej z dnia 13 kwietnia 2016 r. zawierająca powody, dla których Sejm uznaje, że projekt dyrektywy Parlamentu Europejskiego i Rady zmieniającej dyrektywę 96/71/WE Parlamentu Europejskiego i Rady z dnia 16 grudnia 1996 r. dotyczącą delegowania pracowników w ramach świadczeniu usług nie jest zgodny z zasadą pomocniczości. Narodowy Bank Polski, Kursy średnioważone walut obcych w złotych (Tabela A), http://www.nbp.pl/home.aspx?f=/kursy/arch_a.html. 
Główny Urząd Statystyczny, Przeciętne miesięczne wynagrodzenie w gospodarce narodowej w latach 1950-2017, stan na 23 września 2018 roku, https://stat.gov.pl/ obszary-tematyczne/rynek-pracy/pracujacy-zatrudnieni-wynagrodzenia-koszty-pracy/przecietne-miesieczne-wynagrodzenie-w-gospodarce-narodowej-wlatach-1950-2017,2,1.html.

\section{Literatura}

Bokhorst D., Schout A., Wiersma J.M., The Emperor's New Clothes? A Political Evaluation of the Early Warning Mechanism, "The International Spectator" 2015, Vol. 50, No. 2.

Dür A., Measuring Interest Group Influence in the EU. A note on Methodology, European Union Politics, SAGE Publications, vol. 9, 2008.

Eurofound, Statutory minimum wages in 2015: Pay - Q4 2014 (EurWORK topical update), Eurofound, 2017.

Jancic D., The game of cards: National Parliaments in the EU and the future of the Early Warning Mechanism and the political dialogue, "Common Market Law Review" 2015, Vol. 52.

\section{Wywiady}

\section{Osobiste}

Urzędnik, Komisja Europejska, Wywiad \#1, Bruksela, 10 kwietnia 2017.

Urzędnik, Wywiad \#2, Bruksela, 10 kwietnia 2017.

Urzędnik, Wywiad \#3, Bruksela, 20 kwietnia 2017.

Urzędnik, DG Employment, Komisja Europejska, Wywiad \#4, Bruksela, 24 kwietnia 2017.

Przedstawiciel parlamentu narodowego, Wywiad \#5, Bruksela, 24 kwietnia 2017.

\section{Poprzez e-mail}

Korespondent IPEX, Bundestag, Wywiad \#7, 5 kwietnia 2017.

Urzędnik, Izba Poselska Republiki Czeskiej, Wywiad \#8, 5 kwietnia 2017.

Urzędnik, Senat Republiki Czeskiej, Wywiad \#9, 7 kwietnia 2017.

Urzędnik, Sejm Rzeczypospolitej Polskiej, Wywiad \#10, 14 kwietnia 2017.

Korespondent IPEX, Bundesrat, Wywiad \#11, 24 kwietnia 2017. 